\title{
College Adaptation Among Colombian Freshmen Students: Internal Structure of the Student Adaptation to College Questionnaire (SACQ)
}

\author{
Marbel Lucia Gravini Donado ${ }^{1}$, Mabel Mercado-Peñaloza ${ }^{1}$ (D) and Sergio Dominguez-Lara ${ }^{2}$ (i) \\ ${ }^{1}$ School of Legal and Social Sciences, Universidad Simon Bolívar, Colombia \\ ${ }^{2}$ Vice Rectorate for Research, Universidad Privada San Juan Bautista, Perú
}

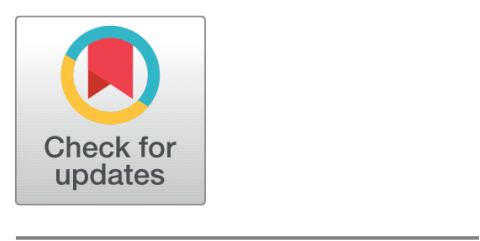

Received 2020-10-01
Revised 2020-10-22
Accepted 2020-12-15
Published 2021-07-15

Corresponding Author Marbel Lucia Gravini Donado, mgravini1@unisimonbolivar.edu. co

Cra 54 No 59-92, 0800002 , Barranquilla, Colombia.

DOI https://doi.org/10.7821/ naer.2021.7.657

Pages: 251-263

Distributed under

Creative Commons CC BY 4.0

Copyright: (C) The Author(s)

\section{OPEN ACCESS}

\section{ABSTRACT}

The aim of this research is to assess the internal structure and reliability of the Student Adaptation to College Questionnaire (SACQ) in a sample comprising 739 students (64\% of them women), attending second-half classes at a private university in the Caribbean Region of Colombia. The SACQ is a 67-item self-report that evaluates four aspects related to university adjustment namely, the academic, institutional, social, and personal-emotional areas. To fulfill its goals, different measurement models were assessed through various confirmatory factor analyses, and the results indicate that the Peruvian model (four dimensions, 27 items) has the best statistical adjustment, presenting evidence in support of its internal structure. Similarly, high reliability indicators were obtained, both with regard to the construct and scoring. In conclusion, the SACQ's psychometric properties are satisfactory as regards its internal structure (tetra-factorial model) and reliability, enabling its use to evaluate adjustment to college life.

\section{Keywords DROPPING OUT, STUDENT ADJUSTMENT, FACTORIAL ANALYSIS, QUESTIONNAIRE}

\section{INTRODUCTION}

Remaining in the higher education system has become a challenge for young people due to multiple factors related to institutional, academic, social, and emotional components that they must face (Araque, Roldán, \& Salguero, 2009; Ethington, 1990; Tinto, 1975). These factors affect students' continuation of university studies and can cause them to drop out. Dropouts can be understood from two perspectives: by period and by group. Dropouts by period refer to the percentage of students who stopped enrolling for two academic periods, that is, they did not report enrollment in the last two semesters. This is important to identify in order to follow-up in the short term. Dropouts by group correspond to following up with students who enrolled in a specific group or class year and accounts for all dropouts that correspond to said group compared to those enrolled. This comparison is made when the 
group is in its last semester, that is, it is a retrospective dropout indicator for the entire duration of the degree program. In Colombia, for example, the System for the Prevention and Analysis of Dropouts in Higher Education Institutions [SPADIES, for its Spanish acronym] indicates that the dropout percentage per academic period at the university level is $9 \%$, and by group in university professional programs it is $45.1 \%$. These figures vary based on the level of training. If compared with professional technical programs, the dropout rate per period is $26.1 \%$ and it is $52.3 \%$ per group 52 (Ministerio de Educación Nacional, 2016).

Unfortunately, this statistic will increase in the coming years as a result of the current circumstances that the world is experiencing due to the COVID-19 pandemic. There are various reasons that partially explain dropouts, but today this situation is gaining more prominence. A fundamental reason for this is the inevitable economic recession that the pandemic will provoke. In Latin America, in particular, levels of access and coverage of public higher education are low, so many young people are forced into struggling financially to enroll in private universities, which have greater coverage due to measures such as financing and scholarships (Ferreyra, Avitabile, Botero Alvarez, Haimovich Paz, \& Urzúa 2017) (Ferreyra, Avitabile, Alvarez, Paz, \& Urzúa, 2017). In addition to the economic factors that can lead to dropouts at this time, known as the COVID and post-COVID stage, other reasons have been exacerbated that could be related to students' motivation to remain in school. These are associated with quarantine, family environment, adapted curricula generated by remote or virtual education and, especially, young people's mental health (Huckins et al., 2020; Li, Cao, Leung, \& Mak, 2020). Regarding the latter, students who demonstrate good emotional adaptation will have better tools or resources to face current changes in the higher education system.

This is relevant given that a UNESCO report (2020) explains that the loss of socialization in the in-person university environment and also isolation will have a negative impact on students' emotional stability and will especially be exacerbated in those with a history of emotional problems. Students who require academic and pedagogical support and reinforcement face a similar situation. Therefore, it is imperative that universities and higher education centers redouble their efforts and establish support plans for this at-risk population in order for them to continue their studies.

Validated assessment instruments and scales are necessary to serve as a reference to characterize young university students and generate support alternatives. Therefore, validating the existing tests regarding university adaptation is very useful, both in normal circumstances, if we return to these soon; during the pandemic, and after, in what has been called the new normal.

In addition, because there is no precedent for university adaptation in a global pandemic, studies on the subject from before quarantine are referred to, which are detailed below. A conclusion of these studies that should be noted is the importance of the first academic courses or semesters, since they are a transition period and entail changes related to various factors and, likely, some students are not prepared to face those challenges (Credé \& Niehorster, 2012; Soledad, Carolina, Adelina, Fernández, \& Fernanda, 2012). In this way, if this period is perceived as difficult by the students, their adaptation to the new environment 
would be affected (Londoño, 2009).

In this sense and given the importance of these first periods of higher education, which are the most susceptible to experiencing dropouts (Willcoxson, 2010), it is important to consider the reasons students are attending university, among which professional perspective, university status, location, social environment, and emotional components stand out (van Herpen, Meeuwisse, Hofman, Severiens, \& Arends, 2017). Therefore, both international and national Higher Education Institutions [HEIs] generate and implement strategies and tools to meet the needs of first-time students and facilitate their adaptation to university life [AUL] in areas that need be strengthened.

AUL refers to students' ability to handle demands and operate autonomously at the university (Feldt, Graham, \& Dew, 2011). It is a concept that has been gaining great importance in educational research, particularly those related to higher education dropout rates. This can be characterized by four dimensions: academic, social, personal-emotional, and institutional. Academic adaptation refers to how students face the new ways of teaching and evaluating, the academic requirements and responsibilities that they must undertake in this new context (Ramsay, Barker, \& Jones, 1999); meanwhile, social adaptation is related to students' ability to alternate their academic life with their family, social and even work life (MEN, 2009). Personal-emotional adaptation is understood as students' ability to face this new stage in which they must make adjustments toward autonomy, responsibility, and relationships with themselves and others. Finally, institutional adaptation consists of the perception and satisfaction that students ascribe to the institution they choose for their higher education.

When students achieve a satisfactory adaptation to the academic life offered by the university, and find it compatible with their interests, as well as respond appropriately to the academic requirements in their first year of higher education, they will have greater opportunities to remain in school and complete their program (Castaño, Gallón, Gómez, \& Vásquez, 2006).

In this sense, we reference studies on the importance of these dimensions in the university environment. For example, in relation to social adaptation, student participatory processes through intercultural projects promote positive changes in interpersonal relationships (Caetano, Freire, \& Machado, 2020). Thus, this must be considered for social adaptation in higher education, since it is a space where students interact with different social and cultural groups. In addition, some researchers agree on the need to implement guidance programs that support institutional adaptation for students in their first year of academic life. This allows them to integrate with their peers (Braxton \& McClendon, 2002). Also, academic strategies contribute to the development of skills necessary for academic success (Connolly, Flynn, Jemmott, \& Oestrei-Cher, 2017). Finally, the emotional dimension cannot be ignored since mental health is one of the key elements in everyone's life and that in this time of the pandemic, has been significant (Huckins et al., 2020).

For the reasons described above, student characterization has become a relevant process for projects to be established and actions carried out based on the information obtained. In this way, the risks of dropouts are minimized, and the necessary competencies can be 
developed to achieve academic success. For example, in some universities, knowledge of freshmen students' level of achievement in mathematics and reading serves to implement strategies to strengthen their competencies. This is done using leveling and reinforcement courses in these areas in order to prevent or reduce the number of students who fail courses related to basic competencies and, as a result, those who participate in these leveling processes remain in school (Arrieta \& Mercado, 2018). In addition, the results of studies that are related to the risk of dropouts contribute to the well-being of young people, as well as that of society, institutions, governments, and, indirectly, businesses (Bonaldo \& Pereira, 2016).

However, despite the importance and relevance of the AUL assessment, there are few existing tools that allow for standard measurement in Latin America. For example, there is the Spanish version of the Academic Experience Questionnaire, a shortened version (QVAr; Almeida, Ferreira, \& Soares, 1999) and the AUL Questionnaire (CAVU; Rodríguez-Ayan \& Sotelo, 2014) created in Spanish, but both have limitations regarding the factorial analytical procedures used in their construction. Specifically, in both cases they use principal component analysis as a factor extraction method, despite being widely rejected by the specialized literature (Ferrando \& Anguiano-Carrasco, 2010; Lloret-Segura, Ferreres-Traver, Hernández-Baeza, \& Tomás-Marco, 2014; Watkins, 2018), which questions its potential use in university contexts.

In addition to the aforementioned scales, a measure that has gained relevance is the SACQ; Baker \& Siryk, 1989) due to the ample evidence of its association with academic and personal variables related to the academic context of first-year students (Credé \& Niehorster, 2012). The instrument offers four dimensions that are considered essential for adaptation among students who have recently enrolled in HEIs: academic adaptation, social adaptation, personal-emotional adaptation, and institutional adaptation, in addition to a general adaptation measure.

However, while its factorial structure has not remained stable compared to the number of items per dimension, at least four independent psychometric studies have satisfactorily normalized the four underlying dimensions, although there were differences in terms of the item distribution (Carayon \& Gilles, 2005; Dominguez-Lara, Prada-Chapoñan, \& GraviniDonado, 2019; Soledad et al., 2012; Taylor \& Pastor, 2007).

One of these adaptations was conducted in Peru (Dominguez-Lara et al., 2019) and obtained favorable indicators in terms of its content and showed an internal structure of four dimensions, but without the presence of an overall score. In this study, other measurement models were evaluated (Baker \& Siryk, 1989; Soledad et al., 2012; Taylor \& Pastor, 2007), but they resulted in unfavorable fit indices. There were items that do not adequately represent the construct, poor specifications associated with unspecified cross-loads, and a large number of inverted items negatively affected the factorial structure (for more detail, see Dominguez-Lara et al., 2019).

In this way, the existence of a model used in Peru is favorable for use in Colombia due to the geographical and cultural proximity that both countries have, although each one has specific characteristics regarding their HEIs. However, considering the preliminary litera- 
ture, it is highly probable that the tetrafactorial structure also receives support.

Thus, the objective of this report was to analyze the internal structure and reliability of the SACQ in Colombian freshmen students (second semester).

The study is justified to the extent that, in Colombia, psychometric studies of scales that assess the AUL are still emerging. We only have data from the adaptation and validation of the Academic Experience Questionnaire-Short Version (QVA-r) (D. M. Rodríguez, Urazán, \& Arango, 2009), which was mentioned above. This same scale was used to identify the dropout risk profile according to socioeconomic, institutional, academic, and individual conditions among students from a Colombian university campus (Ramírez, Velásquez, Zapata, Velásquez, \& Ramírez, 2020). In addition, while there is still no evidence on the use of the SACQ in student retention programs, its dimensions have shown negative relationships with the intention of dropping out (Slick \& Lee, 2014) and positive relationships with the intention of remaining enrolled (van Rooij, Jansen, \& van de Grift, 2017). Finally, there is a pressing need for the field of higher education to have instruments with evidence of validity in the newly enrolled Colombian university population. By completing the first semesters of their degree program, students are able to offer a realistic appreciation of how their transition to college has gone.

\section{MATERIALS AND METHODS}

The Student Adaptation to College Questionnaire (SACQ; Baker \& Siryk, 1989) is a selfreport that consists of 67 items with 9 options in Likert format (from completely disagree [1] to completely agree [9]), which evaluate four dimensions: academic adaptation, institutional adaptation, social adaptation, and personal-emotional adaptation. The instructions are geared toward describing their most recent college experience. The full version adapted to Spanish spoken in Peru was used (Dominguez-Lara et al., 2019).

\subsection{Sample}

The sample was made up of 739 students (64\% women) in their second semester of studies at a private university on the Caribbean coast of Colombia, between the ages of 16 and 42 years $(\mathrm{M}=19.013 ; \mathrm{SD}=3.1908 ; 95.670 \%$ between 16 and 25 years old $)$ from different schools (Health Sciences: 248, Administration and Business: 92, Engineering: 144, Legal and Social Sciences: 237, Basic and Biomedical Sciences: 18). The total population for second semester students at the university is 1,470 , of which, $50.27 \%$ responded.

\subsection{Procedure}

To apply the instrument, permission was requested from the institution's Academic ViceRector and Vice-Rector for Research, Expansion, and Innovation. Prior to administrating the SACQ, a focus group was conducted with 15 students to determine if the items were understood. Some minor changes were made to the items (e.g., change cursos [courses] [Peruvian version] to asignaturas [subjects], which is used more in Colombia]). Then, the scale was transferred to a survey format via Googleforms ${ }^{(R)}$ and the link was sent to the 
students through the school's email system after the second evaluation scheduled for the academic semester and was administered by the university department in charge of the student support program, whose role is to monitor strategies to strengthen student retention. The students were informed of the objectives of the assessment and that the data would be used as part of a research study, also indicating that their answers will be kept confidential.

\subsection{Statistical Analysis}

As a preliminary step, multivariate normality was analyzed using the Mardia coefficient (G2), expecting magnitudes less than 70 (Rodriguez \& Ruiz, 2008). The evidence of validity regarding the internal structure was based on the findings of the confirmatory factor analysis (CFA), which was completed based on the robust maximum likelihood estimation method, correcting for non-normality (MLR) and Pearson correlation matrices, given that: 1) the items can be considered continuous variables ( $>6$ response options); and 2 ) it is less sensitive to excess skewness and kurtosis.

In addition to the original model (M1; Baker \& Siryk, 1989), three other models of four oblique factors available in the literature were evaluated: Taylor and Pastor (2007), Soledad et al. (2012), Dominguez-Lara et al. (2019) called M2, M3, and M4, respectively (Table 1).

Table 1 SACQ measurement models

\begin{tabular}{|c|c|c|c|c|}
\hline $\begin{array}{l}\text { Academic adap- } \\
\text { tation }\end{array}$ & $\begin{array}{l}\text { Social adapta- } \\
\text { tion }\end{array}$ & $\begin{array}{l}\text { Institutional } \\
\text { adaptation }\end{array}$ & $\begin{array}{l}\text { Personal-emotional } \\
\text { adaptation }\end{array}$ & $\begin{array}{l}\text { Type of student } \\
\text { assessed }\end{array}$ \\
\hline $\begin{array}{l}3,5,6,10,13,17 \\
19,21,23,25,27 \\
29,32,36,39,41, \\
43,44,50,52,54, \\
58,62,66 .\end{array}$ & $\begin{array}{l}1,4,8,9,14,16, \\
18,22,34,37, \\
42,46,48,51, \\
56,57,63,65\end{array}$ & $\begin{array}{l}1,4,15,16,34,36 \\
42,47,56,57,59 \\
60,61,65 .\end{array}$ & $\begin{array}{l}2,7,11,12,20,24,28, \\
31,35,38,40,45,49, \\
55,64 .\end{array}$ & Freshmen \\
\hline $\begin{array}{l}3,13,17,19,25, \\
29,36,43,50,52, \\
54,62,66 .\end{array}$ & $\begin{array}{l}1,4,8,9,18,26 \\
30,37,46,63 \\
65 .\end{array}$ & $\begin{array}{l}15,16,23,32,34 \\
57,59,60,61\end{array}$ & $\begin{array}{l}2,7,71,11,12,20,21, \\
22,28,31,38,39,40, \\
41,42,45,48,51,56, \\
64 .\end{array}$ & Sophomore \\
\hline $\begin{array}{l}13,19,21,27,29, \\
32,41,43,44,50, \\
52,54,58,62 .\end{array}$ & $\begin{array}{l}1,4,8,9,18,30 \\
37,42,46,51, \\
57,63,65 .\end{array}$ & $\begin{array}{l}5,15,16,34,47,59 \\
60,61 .\end{array}$ & $\begin{array}{l}2,7,11,12,20,28,31, \\
38,40,45,55,64 .\end{array}$ & Freshmen \\
\hline $3,13,27,41$ & $9,18,63,65$ & $5,15,47,50,59,61$ & $\begin{array}{l}2,6,7,11,12,20,28 \\
31,35,38,40,45,64\end{array}$ & Freshmen \\
\hline
\end{tabular}

Rodríguez et al. (2012)

Dominguez-Lara et al. (2019)
As a complement to each model, one in which all the items are influenced by a single latent variable (one-dimensional) was considered, since some studies include the presence of an overall score (e.g., Baker \& Siryk, 1989). In that sense, these were named with an index; for example, M1a would refer to the one-dimensional version of the original model. All analyses were performed with the Mplus v7.0 program (Muthén \& Muthén, 1998-2012).

The measurement models were evaluated using various criteria. The first was based on the magnitude of the most used adjustment indices for procedures such as the CFI $>0.90$ ), SRMR $<0.08$ (McDonald \& Ho, 2002), and the RMSEA, whose upper limit of its confidence interval is expected to be less than 0.10 (West, Taylor, \& Wu, 2012). The second criterion was based on the items' degree of quantitative representativeness compared to the evaluated 
construct, which is expressed in the magnitude of the factor loadings ( $>0.50$; DominguezLara, 2018) and by the mean variance extracted (MVE) per factor, expecting values greater than 0.50 (Fornell \& Larcker, 1981). In addition, reliability was analyzed both in relation to the construct using the coefficient $\omega(>0.70$; Hunsley \& Marsh, 2008) and scores with the coefficient $\alpha$ (>0.80; Ponterotto \& Charter, 2009).

\section{RESULTS}

Regarding the normality analysis, M1 (G2 = 1,293.930), M2 (G2 = 1,055.863), M3 (G2 = $871.127)$, and M4 $(\mathrm{G} 2=295.3632)$ did not meet the multivariate normality $(\mathrm{G} 2>70)$. The fit indices derived from the M1, M2, and M3 models did not reach an adequate magnitude, which provides unfavorable evidence regarding the dimensionality of the SACQ in Colombian students (Table 2), in the same way as each model's one-dimensional variant. In contrast, the Peruvian model (M4) best fits the data: The fit indices (CFI, RMSEA, and SRMR) are within the expected parameters, the factor loadings had a mostly moderate magnitude $(>0.50)$, and $\operatorname{VME}(>0.50)$ was adequate in three of the four dimensions (Table 3$)$. Finally, regarding reliability, high indicators were reached both in relation to construct reliability $(\omega)$ and scores $(\alpha)(>0.80)$.

\begin{tabular}{|c|c|c|c|}
\hline & CFI & RMSEA (IC 90\%) & SRMR \\
\hline \multicolumn{4}{|l|}{ Original } \\
\hline M1: Four factors & 0.816 & $0.056(0.054, .057)$ & 0.087 \\
\hline M1a: Unidimensional & 0.68 & $0.073(0.072,0.075)$ & 0.094 \\
\hline \multicolumn{4}{|l|}{ Taylor \& Pastor } \\
\hline M2: Four factors & 0.792 & $0.064(0.062,0.066)$ & 0.109 \\
\hline M2a: Unidimensional & 0.693 & $0.77(0.076,0.079)$ & 0.092 \\
\hline \multicolumn{4}{|l|}{ Rodríguez et al. } \\
\hline M3: Four factors & 0.856 & $0.057(0.055,0.059)$ & 0.073 \\
\hline M3a: Unidimensional & 0.688 & $0.084(0.082,0.086)$ & 0.098 \\
\hline \multicolumn{4}{|l|}{ Dominguez-Lara et al. } \\
\hline M4: Four factors & 0.91 & $0.056(0.053,0.060)$ & 0.063 \\
\hline M4a: Unidimensional & 0.636 & $0.112(0.109,0.115)$ & 0.141 \\
\hline
\end{tabular}

\section{DISCUSSION AND CONCLUSIONS}

The relevance of AUL lies in the fact that, despite being such an important construct, few Latin American studies cover it. This indicates the need to establish evidence to address an increasingly pressing reality: university dropouts. This aspect is currently recognized as a priority to be addressed at all education levels, but mainly in higher education where the current and future impact seems to be greater, due to the consequences of the global pandemic in 2020. It is clear that students are affected in how they adapt to this new reality, and 
Table 3 Parameters of the items of the Peruvian version of the SACQ in Colombian students

\begin{tabular}{|c|c|c|c|c|}
\hline & F1 & F2 & F3 & F4 \\
\hline Item 5 & 0.827 & & & \\
\hline Item 15 & 0.882 & & & \\
\hline Item 47 & 0.723 & & & \\
\hline Item 50 & 0.822 & & & \\
\hline Item 59R & 0.698 & & & \\
\hline Item $61 \mathrm{R}$ & 0.746 & & & \\
\hline Item 2 & & 0.647 & & \\
\hline Item 6 & & 0.531 & & \\
\hline Item 7 & & 0.754 & & \\
\hline Item 11 & & 0.603 & & \\
\hline Item 12 & & 0.637 & & \\
\hline Item 20 & & 0.643 & & \\
\hline Item 28 & & 0.546 & & \\
\hline Item 31 & & 0.587 & & \\
\hline Item 35 & & 0.333 & & \\
\hline Item 38 & & 0.663 & & \\
\hline Item 40 & & 0.649 & & \\
\hline Item 45 & & 0.707 & & \\
\hline Item 64 & & 0.656 & & \\
\hline Item 3 & & & 0.795 & \\
\hline Item 13 & & & 0.615 & \\
\hline Item 27 & & & 0.825 & \\
\hline Item 41 & & & 0.731 & \\
\hline Item 9 & & & & 0,852 \\
\hline Item 18 & & & & 0,604 \\
\hline Item 63 & & & & 0,579 \\
\hline Item 65 & & & & 0,836 \\
\hline $\mathrm{F} 1$ & 1 & & & \\
\hline $\mathrm{F} 2$ & -0.31 & 1 & & \\
\hline F3 & 0.919 & -0.428 & 1 & \\
\hline $\mathrm{F} 4$ & 0.793 & -0.466 & 0.838 & 1 \\
\hline VME & 0.617 & 0.384 & 0.556 & 0,531 \\
\hline \multicolumn{5}{|l|}{ Fiabilidad } \\
\hline$\omega$ & 0.906 & 0.888 & 0.832 & 0,815 \\
\hline$\alpha$ & 0.905 & 0.885 & 0.825 & 0,809 \\
\hline IC95\% $\alpha$ & $0.891,0.917$ & $0.868,0.900$ & $0.801,0.847$ & $0.783,0.833$ \\
\hline
\end{tabular}

Note: R: inverted item; F1: institutional adjustment; F2: personalemotional adjustment; F3: academic adjustment; F4: social adjustment; AVE: mean variance extracted mean; $\omega$ : omega coefficient; $\alpha$ : alpha coefficient; CI: confidence interval. 
they have expectations regarding institutional strategies to provide educational continuity with excellence and quality, guaranteeing the comprehensive well-being of their students. In this context, the objective of this study was to carry out a structural and reliability-based analysis of the SACQ, which is a scale designed to evaluate AUL, and which is considered a valuable instrument to generate risk indicators in different dimensions that are part of students' academic activity.

In the study, four measurement models corresponding to different educational realities were evaluated. The Peruvian model (Dominguez-Lara et al., 2019) received the most support with the Colombian data. This can be explained in the sense that the SACQ configurations obtained in the other studies (Baker \& Siryk, 1989; Soledad et al., 2012; Taylor \& Pastor, 2007) probably do not consistently reflect the experiences of Colombian students, or some items are not representative of the construct in this sample. In no case did the one-dimensional model receive support, which does not allow for a favorable conclusion regarding the presence of an overall score. Regarding reliability, while the indicators do not fully reach magnitudes typical of individual application scales ( $>0.90$; Nunnally, \& Bernstein, 1994), they are adequate (>0.80; Ponterotto \& Charter, 2009). In this way, a measurement can be achieved with a tolerable measurement error and, as a result, it is more useful for professionals.

However, regardless of which item distribution obtained the best statistical fit, the AUL's four-dimensional model (academic, social, personal-emotional, and institutional adaptation) is viable among the group studied. For this reason, it is worth highlighting that having an instrument with evidence of validity that evaluates the AUL, provides valuable information to identify the possible risks of maladjustment and, as a result, of the dropout and academic failure that it presents in the first semesters of a degree program to be able to act on that information.

As for the practical implications of the findings, several points can be highlighted. While it is true that at the international and national level, strategies have been worked out to promote student retention, it is unlikely that personalized follow-up is carried out and information is obtained from students who, because of their individual characteristics, do not generally seek the support offered by universities to mitigate the risks of dropping out of school. For this reason, the SACQ would enable monitoring from admission to completion of a degree, which facilitates the implementation of effective interventions (knowing which area is deficient and acting accordingly), efficient interventions (using resources rationally through early detection) and timely interventions (to avoid dropouts). In addition, this supports the optimization of resources that the institutions invest in student retention.

Furthermore, the structural characteristics of the SACQ make it possible to take advantage of targeting interventions based on needs. For example, with regard to personal-emotional and social adaptation, the results could help to evaluate and implement strategies that help to reinforce social skills. This is because there is evidence of the effectiveness of an interpersonal skills intervention program in Brazilian university students to reduce social anxiety (Wagner, Pereira, \& Oliveira, 2014). In addition, the need to create comprehensive programs to establish emotional competencies in students 
has been noted (González \& García, 2013), as well as that related to academic adaptation serving as an input for teachers, counselors, or those who lead academic processes. Finally, if there is an opportunity to obtain valid data from the entire population, it will lead to the implementation of improvement proposals in HEIs' institutional development plans.

Also, having favorable psychometric evidence from the SACQ is an opportunity for Colombian HEIs and official institutions in charge of monitoring higher education dropouts to use, or at least assess, the possibility of doing so. This is because a country in which students do not complete their professional degree programs is a reflection of a lack of education quality. In this way, identifying potential cases by using an instrument with evidence of validity in both public and private universities would help prevent student dropouts. In the same way, even when this psychometric report was conducted in a Colombian city, and the cultural differences by regions are clear, the university adaptation processes are not estimated to be different, based on the idea that the items evaluate characteristics that are general to those that young people experience in their academic and social lives at universities. This would allow them to be generalized in other geographical contexts of Colombia. However, the possibility of conducting studies on a larger scale in all regions of the country remains.

Within the limitations that arose in conducting this research study, it is likely that expanding the original instrument generated some kind of disinterest among students, especially those who were not familiar with expanded scales. In this sense, it is highly probable that this shorter version of SACQ (27 items) will be more widely accepted in future generations of new students. In addition, given the scale's expansion, it was not possible to implement some other measures related to the academic field that may be relevant for this process, such as coping or self-efficacy (see Credé, \& Niehorster, 2012), so understanding the degree of association with variables theoretically linked to AUL is still pending.

In conclusion, the SACQ obtained satisfactory psychometric properties in terms of its internal structure (tetrafactorial model) and reliability.

Future studies are recommended to replicate this version of the study, as well as to expand the sample and diversify students from public universities. Expanding the sample could be used to conduct studies that make it possible to compare how AUL is experienced among students from different schools, as well as to develop normative data (scales) that could classify them based on a certain level (e.g., high). Thus, institutions may have a panorama of the risk of their students dropping out. In addition, the predictive capacity of the SACQ dimension's scores on dropout/retention or with academic performance could be analyzed. While the association observed in meta-analytic studies is modest (Credé \& Niehorster, 2012), it should still be explored since this is a different context. Furthermore, as already mentioned, one of the limitations was the lack of measurements on other constructs associated with AUL to provide evidence of validity due to their relationship with other variables. Thus, it is necessary to implement these aspects in a subsequent study in order to strengthen the measurement. Finally, the perspective of university adaptation should be broadened to distance education as well, since although it is the established modality due to the COVID-19 pandemic, many universities were already using this modality in parallel 
with in-person learning. The university adaptation process could have specific characteristics that are not considered in traditional scales since aspects such as socialization that can be more associated with in-person contexts (e.g., interaction with peers) are different in the virtual learning environment, in which other spaces and resources are developed for classmates and teachers to socialize.

\section{REFERENCES}

Almeida, L., Ferreira, J., \& Soares, A. (1999). Questionário de vivências académicas (QVA e QVAr). Universidade do Minho / Universidade de Coimbra.

Araque, F., Roldán, C., \& Salguero, A. (2009). Factors influencing university drop out rates. Computers \& Education, 53(3), 563-574. https://doi.org/10.1016/j.compedu.2009.03.013

Arrieta, L., \& Mercado, M. (2018). Nivelatorios: Estrategia para mitigar deserción académica precoz. Universidade do Minho / Universidade de Coimbra.

Baker, R. W., \& Siryk, B. (1989). Student Adaptation to College Questionnaire (SACQ): manual. Western Psychological Services.

Bonaldo, L., \& Pereira, L. N. (2016). Dropout: Demographic Profile of Brazilian University Students. Procedia - Social and Behavioral Sciences, 228, 138-143. https://doi.org/10.1016/j.sbspro.2016 .07 .020

Braxton, J. M., \& McClendon, S. A. (2002). The Fostering of Social Integration and Retention through Institutional Practice. Journal of College Student Retention: Research, Theory \& Practice, 3(1), 57-71. https://doi.org/10.2190/rgxj-u08c-06vb-jk7d

Caetano, A. P., Freire, I. P., \& Machado, E. B. (2020). Student Voice and Participation in Intercultural Education. Journal of New Approaches in Educational Research, 9(1), 57-73. https://doi.org/ 10.7821/naer.2020.1.458

Carayon, S., \& Gilles, P. (2005). Développement du questionnaire d'adaptation des étudiants à l'université (Q.A.E.U.). Lorientation Scolaire et Professionnelle, 34, 165-189. Retrieved from https://journals.openedition.org/osp/463https://doi.org/10.4000/osp.463

Castaño, E., Gallón, S., Gómez, K., \& Vásquez, J. (2006). Análisis de los factores asociados a la deserción y graduación estu-diantil universitaria. Lecturas de Economía, 65, 9-36.

Connolly, S., Flynn, E., Jemmott, J., \& Oestrei-Cher, E. (2017). First Year Experience for At-Risk College Students. College Student Journal, 51(1), 1-6.

Credé, M., \& Niehorster, S. (2012). Adjustment to College as Measured by the Student Adaptation to College Questionnaire: A Quantitative Review of its Structure and Relationships with Correlates and Consequences. Educational Psychology Review, 24, 133-165. https://doi.org/ 10.1007/s10648-011-9184-5

de Educación, M., \& Nacional. (2016). Reporte sobre deserción y graduación en educación superior. Año 2016. Retrieved from https://www.mineducacion.gov.co/sistemasdeinformacion/1735/ articles-357549_recurso_5.pdf

Dominguez-Lara, S. (2018). Propuesta de puntos de corte para cargas factoriales: una perspectiva de fiabilidad de constructo. Enfermería Clínica, 28(6), 401-402. https://doi.org/10.1016/j.enfcli .2018.06.002

Dominguez-Lara, S., Prada-Chapoñan, R., \& Gravini-Donado, M. (2019). Estructura interna del Student Adaptation to College Questionnaire (SACQ) en universitarios de primer año. https:// doi.org/10.1016/j.edumed.2019.06.004

Ethington, C. A. (1990). A psychological model of student persistence. Research in Higher Education, 31(3), 279-293. https://doi.org/10.1007/bf00992313 
Feldt, R. C., Graham, M., \& Dew, D. (2011). Measuring Adjustment to College: Construct Validity of the Student Adaptation to College Questionnaire. Measurement and Evaluation in Counseling and Development, 44(2), 92-104. https://doi.org/10.1177/0748175611400291

Ferrando, P. J., \& Anguiano-Carrasco, C. (2010). El análisis factorial como técnica de investigación en psicología. Papeles del Psicólogo, 31(1), 18-33.

Ferreyra, M., Avitabile, C., Alvarez, J. B., Paz, F. H., \& Urzúa, S. (2017). At a Crossroads, Higher Education in Latin America and the Caribbean. International Bank for Reconstruction and Development. The World Bank.

Fornell, C., \& Larcker, D. F. (1981). Evaluating structural equation models with unobservable variables and measurement error. Journal of Marketing Research, 18, 39-50. https://doi.org/ $10.1177 / 002224378101800104$

González, M. L. G., \& García, C. L. (2013). Competencias emocionales y rendimiento académico en estudiantes universitarios. Revista Electrónica Interuniversitaria de Formación del Profesorado, 16(2), 13-25. https://doi.org/10.6018/reifop.16.2.181031

Huckins, J. F., Dasilva, A. W., Wang, W., Hed-Lund, E., Rogers, C., Nepal, S. K., ... Campbell, A. T. (2020). Mental Health and behavior of college students during the early phases of the COVID19 pandemic: Longitudinal smartphone and ecological momentary assessment study. Journal of Medical Internet Research, 22(6), e20185. https://doi.org/10.2196/20185

Hunsley, J., \& Marsh, E. J. (2008). Developing criteria for evidence-based assessment: An introduction to assessment that work (J. H. E. J. Marsh, Ed.). Oxford University Press. https://doi.org/ 10.1093/med-psych/9780190492243.003.0001

Li, H. Y., Cao, H., Leung, D. Y., \& Mak, Y. W. (2020). The Psychological Impacts of a COVID19 Outbreak on College Students in China: A Longitudinal Study. International Journal of Environmental Research and Public Health, 17(11), 3933-3933. https://doi.org/10.3390/ ijerph 17113933

Lloret-Segura, S., Ferreres-Traver, A., Hernández-Baeza, A., \& Tomás-Marco, I. (2014). El análisis factorial exploratorio de los ítems: una guía práctica, revisada y actualizada. Anales de Psicología, 30(3), 1151-1169. https://doi.org/10.6018/analesps.30.3.199361

McDonald, R. P., \& Ho, M.-H. R. (2002). Principles and practice in reporting structural equation analyses. Psychological Methods, 7(1), 64-82. https://doi.org/10.1037/1082-989x.7.1.64

Ministerio de Educación Nacional. MEN. (2009). Deserción estudiantil en la educación superior colombiana. Metodología de seguimiento, diagnóstico y elementos para su prevención. Retrieved from https://www.mineducacion.gov.co/sistemasdeinformacion/1735/articles-254702_libro _desercion.pdf

Muthén, L. K., \& Muthén, B. O. (1998-2012). Mplus User’s Guide. Muthén \& Muthén.

Nunnally, J. C., \& Bernstein, I. H. (1994). Psychometric theory. McGraw-Hill.

Ponterotto, J. G., \& Charter, R. A. (2009). Statistical Extensions of Ponterotto and Ruckdeschel's (2007) Reliability Matrix for Estimating the Adequacy of Internal Consistency Coefficients. (Vol. 108, pp. 878-886). SAGE Publications. https://doi.org/10.2466/pms.108.3.878-886

Ramírez, S. M. R., Velásquez, D. U., Zapata, E. P., Velásquez, C., \& Ramírez, E. M. H. (2020). Perfiles de riesgo de deserción en estudiantes de las sedes de una universidad colombiana. Revista de Psicología, 38(1), 275-297. https://doi.org/10.18800/psico.202001.011

Ramsay, S., Barker, M., \& Jones, E. (1999). Academic Adjustment and Learning Processes: a comparison of international and local students in first-year university. Higher Education Research \& Development, 18(1), 129-144. https://doi.org/10.1080/0729436990180110

Rodríguez, D. M., Urazán, S. O., \& Arango, M. R. (2009). Cuestionario de Vivencias Académicas en su versión reducida (QVA-r): un análisis psicométrico. Revista Colombiana de Psicología, $18(1), 33-52$. 
Rodríguez, M., \& Ruiz, M. (2008). Atenuación de la asimetría y de la curtosis de las puntuaciones observadas mediante transformaciones de variables: Incidencia sobre la estructura factorial. Psicológica, 29, 205-227.

Rodríguez-Ayan, M. N., \& Sotelo, M. E. (2014). Cuestionario de adaptación a la vida universitaria (CAVU): desarrollo, estructura factorial y validación inicial. Revista Argentina de Ciencias del Comportamiento, 6(3), 40-49.

Slick, S. N., \& Lee, C. S. (2014). The Relative Levels of Grit and Their Relationship with Potential Dropping-Out and University Adjustment of Foreign Students in Korea. Journal of Digital Convergence, 12(8), 61-66. https://doi.org/10.14400/jdc.2014.12.8.61

Soledad, R. G. M., Carolina, T. V., Adelina, G. C. M., Fernández, P., \& Fernanda, M. (2012). The Student Adaptation to College Questionnaire (SACQ) for Use with Spanish Students. Psychological Reports, 111(2), 624-640. https://doi.org/10.2466/08.10.20.pr0.111.5.624-640

Taylor, M. A., \& Pastor, D. A. (2007). A Confirmatory Factor Analysis of the Student Adaptation to College Questionnaire (Vol. 67). SAGE Publications. Retrieved from https:/dx.doi.org/ 10.1177/0013164406299125 10.1177/0013164406299125

Tinto, V. (1975). Dropout from Higher Education: A Theoretical Synthesis of Recent Research. Review of Educational Research, 45(1), 89-125. https://doi.org/10.3102/00346543045001089

UNESCO. IESALC. (2020). Covid 19 y Eduación Superior: De los efectos inmediatos al día después. Análisis de impactos, respuestas, politicas y recomendaciones. Retrieved from http://www.iesalc .unesco.org/wp-content/uploads/2020/05/COVID-19-ES-130520.pdf

van Herpen, S. G. A., Meeuwisse, M., Hofman, W. H. A., Severiens, S. E., \& Arends, L. R. (2017). Early predictors of first-year academic success at university: pre-university effort, pre-university self-efficacy, and pre-university reasons for attending university. Educational Research and Evaluation, 23, 52-72. https://doi.org/10.1080/13803611.2017.1301261

van Rooij, E. C., Jansen, E. P., \& van de Grift, W. J. (2017). Secondary school students' engagement profiles and their relationship with academic adjustment and achievement in university. Learning and Individual Differences, 54, 9-19. https://doi.org/10.1016/j.lindif.2017.01.004

Wagner, M., Pereira, A., \& Oliveira, M. (2014). Intervención sobre las dimensiones de la ansiedad social por medio de un programa de entrenamiento en habilidades sociales. Psicología Conductual, 22(3), 423-440.

Watkins, M. W. (2018). Exploratory Factor Analysis: A Guide to Best Practice. Journal of Black Psychology, 44(3), 219-246. https://doi.org/10.1177/0095798418771807

West, S. G., Taylor, A. B., \& Wu, W. (2012). Model fit and model selection in structural equation modeling. In R. H. Hoyle (Ed.), (pp. 209-234). Guilford Press.

Willcoxson, L. (2010). Factors affecting intention to leave in the first, second and third year of university studies: a semester-by-semester investigation. Higher Education Research \& Development, 29(6), 623-639. https://doi.org/10.1080/07294360.2010.501071 